\title{
The Acceleration of Simple Patent: How We Optimize Technology on Indonesian Intellectual and Property Rights Law (Study on Central Java, Indonesia)
}

\author{
Waspiah \\ Department of Private and Commercial Law , Faculty of Law, \\ Universitas Negeri Semarang (UNNES), Indonesia \\ Email: waspiahtangwun@gmail.com
}

\begin{abstract}
Problem of intellectual and property rights in Indonesia, as well as Patent, become very important issue that not only affected to the economic development but also to law enforcement and legal area. Laws and regulation in Indonesia before Law No. 14 of 2001 concerning to Patent not directly distinguished a simple patent (paten sederhana) and common patent (paten biasa). The current technological developments encourage industry in business competition, as well as small industries of MSMEs, which have much control over patents. This paper is the result of research in Semarang Regency, Indonesia, in searching and applying technology-based patent acceleration model for UMKM.
\end{abstract}

Keywords-Patent, Simple Patent (Paten Sederhana), Intellectual and Property Rights Law, Small Medium Enterprises (SMES)

\section{INTRODUCTION}

Simple patent becomes a very strategic thing for Indonesia because this type of patent is very closely related to small medium enterprises (SMEs) which grow a lot of fertile and growing in almost all parts of Indonesia. The empowerment of SMEs as mentioned in the preamble of Law Number 20 of 2008 concerning Small Micro Small Medium Enterprises should be optimally and continuously conducted through conducive climate development, giving business opportunity, support, protection, and business development as wide as possible so as to enhance the position, role and potential of SMEs in realizing economic growth, equity and increasing people's income, job creation, and poverty alleviation.

The background of the emergence of Law Number 13 of 2016 concerning Patents (Patents Act) is to refine the old law. The dynamics of the rapidly growing needs that have not yet been accommodated in Law Number 14 of 2001 concerning Patents. The absence of implementing regulations such as Government Regulation on License, Government Regulation on Compulsory License, and so on. Other problems that arise in the case of filing a patent application relatively long and patent fees and patent maintenance costs are relatively still considered expensive for the inventor, which is generally not a big businessman. Therefore, a new system in the regulation of Patents is very urgent and needed as to achieve the national goals on social welfare and welfare state. [1]

The problem now is regarding patent registration that now uses digitalization and technology. The Patents Act, explained that the registration that was using the manual turned into e-filling becomes a need to facilitate Applicants who want to register their Invention to be protected Patent. With e-filing system the application submission becomes simple, fast, and the cost of the applicant (in addition to Patent registration fee) becomes cheaper. So that in the new Patents Act patent application can be submitted manually or electronically, in accordance with Article 24 (4) of the new Patents Act. Application of e-filing is very appropriate with the geographical conditions of Indonesia as an archipelago country. E-filing services will be very effective and efficient to improve patent protection in the country.

In Indonesia especially Central Java more specifically in Semarang regency, many patents, especially simple patents are generated by SMEs, the problem that arises is how simple patents can be registered for protection of law. This is in contrast to the registration of brands whose procedures are easier. If compared with China, China is one of the few countries that produce the simplest patent1, based on data from the Chinese Patent Office,[2] a simple patent registration that has been protected until November 2012 from domestic registration of 2,610,888 simple patents.[3] The number of simple patents that have been protected in China has become the backbone of China's SME-based industry revival. Many new industries grow and thrive in China because they have applied simple patents. A variety of new products and tools are the result of their simple patent development and contain the economic value generated by many Chinese countries. Based on data from the Ministry of Commerce of the United States, currently various provinces in China began to grow its SME-based industry sector due to the many industries that adopt simple patents. This strategy is proven to stimulate the growth of innovation and new economic growth based on simple patents. China's ability to produce new industries based on simple patents is enormously large, we can see from the many exports of tools and products produced by the Chinese state to various countries.

The Statistics of Intellectual Property Application in Indonesia for the past 5 years can be seen in the following table: 
Table 1 Intellectual Property Statistics Statement The last 5 years

\begin{tabular}{|c|c|c|c|c|c|}
\hline \multirow{2}{*}{ Year } & \multicolumn{4}{|c|}{ Type of Intellectual Property Rights } & \multirow{2}{*}{ Total } \\
\cline { 2 - 5 } & Brand & Patent & Design of Industry & 5763 & 80235 \\
\hline 2015 & 61711 & 8857 & 3904 & 5678 & 78681 \\
\hline 2014 & 60984 & 8337 & 3682 & 6287 & 81272 \\
\hline 2013 & 62949 & 7780 & 4256 & 6134 & 80194 \\
\hline 2012 & 62455 & 7026 & 4579 & 5591 & 69075 \\
\hline 2011 & 53196 & 6123 & 4165 & & \\
\hline
\end{tabular}

Source: Ministry of Law and Human Rights

(Kemenkumham), Central Java Office, 2016. [4]

Based on the above table it can be observed that the patent application is far behind from the application of the mark. This is due to several factors that one of the application procedures with the old law is not partial to the SMEs based on simple Patents based on the results of previous studies in comparison with the latest Law that uses E-Filling technology as a system to check how data related to Intellectual Property.

It is interesting to be observed how the Model of Acceleration of Patent Registration-Based Technology Registration at SMEs Semarang District. Based on the above background so it needs to be examined how the Model Acceleration Registration Patent Simple Based Technology at SMEs Semarang Regency.

\section{RESEARCH METHOD}

Data on this research obtained by conducting interview, observation and interpretation of some related documents. In accordance with the paradigm of constructivism and hermeneutic approach then in observation the researcher takes a position as a facilitator by using the principle of participatory. In-depth interviews were conducted with open-ended questions but did not rule out being closed especially with informants who had a lot of information. The research used qualitative approach analysis, interactive analysis models. The research, conducted on Semarang Regency, Central Java Indonesia, with comparing laws and regulations and interviewing some SMEs practitioners. This research was conducted in some UMKM in Semarang Regency built by Department of Cooperatives, Micro Enterprises, Industry and Trade of Semarang Regency which become partner of Metal Service Unit of Semarang Regency, among others is UD. Aryani (Ungaran), Teguh Jaya Teknik (Kalongan, East Ungaran), Karya Hasta
Teknik (Talun , Bergas Lor, Ungaran), Megatama Teknik (Mapagan, West Ungaran) and the Department of Cooperatives, Micro Enterprises, Industry and Trade of Semarang Regency (Ungaran).

\section{RESULT AND DISCUSSION}

\section{A. Models of Accelerated Registration of Simple Patent Based on Information Technology at UMKM Semarang Regency}

Small Medium Micro Enterprises (SMEs) in Semarang Regency generally grow naturally and grow because of the potential or skill possessed by each entrepreneur or business actor, and because of the ability of production, the demand of a certain area and the potential that support to be utilized by business actors, such as the availability of raw materials or natural resources. SMEs in Semarang District are generally owned by local businessmen meaning that they have the ability to produce certain goods and the demand and intelligent predicting opportunities in the community needs.

Semarang Regency Metal Service Unit is a work unit managed professionally with nonprofit principle which has duty and function to give service to company or perpetrator of small and medium industry, including printing business actors or new entrepreneur. The Metal Service Unit of Semarang Regency also conducts activities such as non-regular training to educate potential machine tool operators, provide service of metal machinery / equipment, manufacture of spare parts, as well as service of machinery and manufacturing place for SMEs requiring metal, technical, management and entrepreneurship to small metal industry in Semarang Regency.

Table 2 Partners Metal Service Unit of Semarang Regency

\begin{tabular}{|l|l|l|l|}
\hline Name of Company & Owner & Address & Main Product \\
\hline Teguh Jaya Teknik & Teguh Widodo & Kalongan, East Ungaran & Machinery / Engineering Equipment \\
\hline Megatama Teknik & Sarwono & $\begin{array}{l}\text { Patimura St. No. 10A, Mapagan, } \\
\text { West Ungaran }\end{array}$ & Machinery / Engineering Equipment \\
\hline UD. Aryani & Kasmani & Gurita St. No. 66 Ungaran & Wood Machinery \\
\hline Karya Hasta Teknik & Marjuki & Talun, Bergas Lor & $\begin{array}{l}\text { Engineering Equipment and, Livestock } \\
\text { Farming }\end{array}$ \\
\hline
\end{tabular}

Source: Data of Metal Service Unit of Semarang

Regency[5] 
So far a number of SMEs have utilized facilities owned by Metal Service Unit of Semarang Regency, among others:

1. Teguh Jaya Teknik, the business owned by Teguh Widodo produces machinery or engineering equipment. Equipment engineering itself is the application of science into simple engineering products that can be used to help daily human life. Tools or technology produced from Teguh Jaya Teknik itself covers several fields, namely agricultural equipment, household appliance and industrial tool. Innovations that have been invented by Teguh Jaya Teknik are among others kerupuk (crackers) dryer machine, oil filter machine, cassava chopper machine, coffee grinder machine.

2. Megatama Teknik, the business owned by $\mathrm{Mr}$. Sarwono produces engine or engineering equipment. Innovation invented by Mr. Sarwono from Megatama Teknik consists of several fields namely industrial and agricultural tools. Examples of innovations that have been generated by Megatama Techniques include lathe, emping machine, pound machine, oil filter.

3. UD. Aryani, the business owned by Mr Kasmani produces products or tools in the field of timber. Many innovations are found that are useful for business actors in the field of wood such as cutting machines, woodworking machines, goods lifts.

4. Karya Hasta Teknik, the business owned by Mr. Marjuki produces engineering equipment, timber and livestock equipment. Innovations invented by Hasta Teknik Works, among others, such as lathe, spinner, milk press machine, bread oven, drill machine, cutting machine, woodworking machine.

B. Result of Variety of SMEs Innovation in Semarang Regency, Partners of Metal Service Unit of Semarang Regency

Industry is a pre-eminent sector in Semarang regency, making it a top priority of economic development without neglecting development in other sectors. The

\section{Models of Accelerated Registration of Simple Patent Based on Information Technology at SMEs Semarang Regency}

SMEs of Semarang Regency that have findings in the field of technology, in applying for patent can be through the District Government first, in this case the Department of Cooperatives, Micro Enterprises, Industry and Trade Semarang regency for easier. The application for patent registration may be made by two events, electronic and non-electronic, if by non-electronic means, by filing an application file. Such application files may be submitted independently or through local government assistance. The application file that has reached the Department of Cooperatives, Micro Enterprises, Industry and Trade of Semarang Regency will still be checked again, after the requirement of the request has fulfilled the requirements, it will be sent to the Regional Office of Law and Human Rights to be registered. Registration of intellectual property including patents can be directly registered to the Central industrial sector is classified into large industries, small and medium industries and home industries.

Unpredictable global economic condition is very influential on business actors in Indonesia in general and in Semarang regency in particular. Data from the calculation of Gross Regional Domestic Product (GDP) of Semarang Regency in 2014 shows that industrial sector is the biggest contributor to GDP of $40.14 \%$ (GDP at current prices). This is related to the number of large and medium scale industries located in the region of Semarang regency.

However, problems arise for formal small industries that do not have the capital of large and medium industries. Data from the Department of Cooperatives, SMEs and Trade Industry Semarang Regency in 2014 shows the opposite condition. There are so many small formal industries in Semarang regency that do not continue their business with temporary stop or stop. According to data from the Department of Cooperatives, SMEs and Trade Industry Semarang regency in 2014, the number of home industries amounted to 9,558 units of business by employing 17,016 workers or in other words the average of each company / business employs \pm 2 workers. Manufacture of woven bamboo and palm sugar to be superior for the household industry. The number of small and medium enterprises 1.614 business units by absorbing labors 13,161 people, on average \pm 8 workers per company. The most for this industry group is the food industry, furniture and furniture and convection.[6]

Some SMEs in Semarang Regency that have been mentioned above have not been listed in the innovation through the Department of Cooperatives, UM District Semarang. The reason for not being listed is the result of innovation, among others, because the SMEs think that it is not necessary to register their innovation and some do not understand how to register their innovation. Therefore it is necessary for the acceleration model of simple patent registration based on information technology at SMEs in Semarang Regency, especially for simple patent registration.

Java Regional Office of Law and Human Rights, but SMEs is assisted by the Department of Cooperatives, Micro Enterprises, Industry and Trade of Semarang Regency to be facilitated by registering through the Agency (Dinas) first, then after selection and in select from the service then it can be directly submitted to the Central Java Legal and Human Rights Office. Completed requirement and file of application will be given to the Regional Office of Law and Human Rights of Central Java Province to be sent directly to General Directorate of Intellectual Property in Tangerang for processing of patent registration and making of patent certificate. The application for registration is processed by General Directorate of Intellectual Property until the patent certificate is issued. Similar to electronic means, SMEs built can file the file electronically, either independently or through the relevant agencies.

In practice, in Regency of Semarang, there are no MSMEs that have registered their invention. In fact, many MSMEs are registering many brands. This is related to the 
lack of legal understanding of the benefits and usefulness of patent registration by SMEs, UMKM legal culture is reflected from its lack of consciousness for the protection of Inventory registration law. This is based on the results of research conducted on SMEs in Semarang regency that Patent registration is not important, this is because in their opinion the patent is not important to be registered or the importance of their products sold in the market and if there are imitations of their products, according to them is not a problem.

So actually a lot of ease that is given by Kemenkumham associated with registration KI start from the registration process until the development of registration that can be accessed directly by the registration because all are online. It's just that in the field implementation of many obstacles, especially SMEs Semarang regency. So that the model is expected to be a solution in the Acceleration of patent registration based on information technology in SMEs Semarang District, among others:

1. Maximum mentoring model either from the central government in this case Kemenkumham and Kemenkumham Central Java Office which then seriously to actually accompany SMEs related innovations of high economic value in collaboration with the relevant agencies in this case is the Department of Cooperatives SMEs Industry and Trade of Semarang Regency.

2. The long flow of registration makes the process of registration innovation by SMEs, that the flow of registration must pass through Kemenkumham because it has a certain code, but with information technology should cut the flow of bureaucracy. It should be as if the service can directly register Intellectual Property in this case is a simple patent of SMEs, without having to pass through Kemenkumham Regional Offices in the province, but can go directly to the General Directorate of Intellectual Property.

3. Furthermore, it is necessary to have Special Training on Human Resources (HR) in special units in Department of Industry and Commerce (Disperindag) spread in Indonesia, especially training such as consultant of Intellectual Property which number is

\section{Barriers to the Application of Simple Patent Application Acceleration Models \\ 1. The Role of Government}

Obstacles from the Department of Cooperatives, Micro Enterprises, Industry and Trade Semarang regency related to the implementation of the principal tasks of the Office of Cooperatives, Micro Enterprises, Industry and Trade Semarang District and Local Government of Semarang regency is one of them is to coordinate and service UMKM in Semarang regency, in the implementation of coordination and supervision services on the protection of Intellectual Property registration law is the problem is the lack of human resources. The lack of special education and socialization regarding the importance of the registration of technological innovation to MSMEs is also one of the factors why there are still many MSMEs who are very limited in Indonesia. To become an Intellectual Property consultant is almost the same as an advocate or a lawyer. To become an IP Consultant one must attend training held by the Directorate General of Intellectual and Property Rights in cooperation with the University (Article 1 (4) and Article 4(1) Regulations No. 2 of 2005 on Intellectual Property Rights Consultant). In contrast to the requirement to become an Advocate, a Bachelor of Law must follow PKPA, take PERADI or KAI exams and apprenticeship for at least 2 (two) years continuously at the Advocate office (Article 3 paragraph [1] letter g Act No. 18 of 2003 on Advocates). Meanwhile, to become IPR Consultant we can directly practice after following the inauguration of IPR consultant and inaugurated by the Minister of Law and Human Rights. From the above explanation can be said that being an IPR consultant the number is not as much as lawyers or advocates, so it is felt less to do or help SMEs in terms of intellectual property, especially in the field of simple patents. So in the sense of need for each region in this case is the local government should have an IPR consultant, it is useful for the acceleration of simple patent registration through information technology in SMEs Semarang regency.

4. These acceleration models will not be implemented properly without the awareness of MSMEs as the owners of the right invention, although in fact SMEs are more in the brand, but it is possible that SMEs can create appropriate technology. Growing awareness on the SME inventors of simple patent inventors with appropriate target socialization. This is related to the legal culture of Indonesian society, especially SMEs producing simple patents. Socialization is less effective without monitoring and evaluation and involving various stakeholders or related to SMEs in Indonesia.

5. Related to Law No. 13 of 2016 which is still new needs special technical supervision in the Service related to Intellectual Property, need the socialization of registration of Intellectual Property online, although Online registration has been since 2014, but the facts in Dinas still using manual system that increasingly complicate the desire of UMKM to wishing to register appropriate technological innovations.

unaware of the importance of intellectual property registration especially patents. Especially with the advancement of technology where anyone can access any news just by hand grip.

\section{SMEs Community Legal Culture}

Public legal awareness of the importance of registering intellectual property especially in the field of patent in Indonesia is still very low, especially in Semarang regency, this is seen from the many findings generated SMEs Partners Metal Service Unit Semarang regency but no one to register all. Legal awareness is of the utmost importance because with low legal awareness it affects the least number of successful patented innovations. Many SMEs do not know about the importance of registering their findings, and do not know the registration procedure. 
This problem also arises due to some additional cases in the field that affect Application of patent registration acceleration model through information technology at SMEs Semarang Regency has obstacles such as:

1. The absence of special regulation related to simple patent either at the level of Local Regulation and Regulation of Regent (Bupati).

2. The absence of a special legal regulation at the regional level concerning patents has resulted in a lack of effective patent-related legal protections so that people are reluctant to register their invention for patent and use in the industrial world.

3. Owners of small industries in which still indifferent to patent registration because they have not understood the benefits of patent registration. They assume that the important products they sell without think about the impact in the future in case of legal problems.

4. Lack of socialization to SMEs industry actors related to simple patent. Lack of

5. socialization to the perpetrators of SMEs industry causes the awareness of industry players to decrease.

6. The role of the Government to be further enhanced to create a favorable patent climate

7. All relevant parties, either the Agency of Intellectual Property, Disperindag and SMEs should really be able to apply the acceleration model of patent commercialization in the industrial world.

\section{CONCLUSION}

SMEs which become the guidance of Regional Government in this case the Department of Cooperatives, UM, Industry and Trade of Semarang Regency, in applying for patent can be through two ways, namely non electronic and electronic. Obstacles experienced by SMEs partners Semarang Regency Metal Service Unit in the implementation of patent registration is divided into two main things, namely obstacles in the aspects of government roles and constraints in the aspects of society directly.

\section{REFERENCES}

[1] Febri Maulana. Menyambut Wajah Baru UU Paten di Indonesia (Undang-Undang No. 13 Tahun 2016 Tentang Paten). Accessed on 29 December 2016

[2] Distribution of Grants for Patents for Utility Model and Design Received from Home and Abroad http://english.sipo.gov.cn, Accessed on 26 June2016

[3] China's Utility Model Patent System: Innovation Driver or Deterrent. http://www.uschamber.com, Accessed on 26 June 2016

[4] Ministry of Law and Human Rights (Kemenkumham), Central Java Office, 2016

[5] Data of Metal Service Unit of Semarang Regency

[6] Data of Semarang Regency, 2015 